\title{
XRD ANALYSIS OF ACTIVATED FOUR-COMPONENT CERAMICS
}

\author{
Nataša Đorđević ${ }^{1}$, Jasmina Lozanović Šajić ${ }^{2}$, Slavica Mihajlović ${ }^{1}$, Branislav \\ Marković $^{1}$
}

Received: December 01, 2021

Accepted: December 10, 2021

\begin{abstract}
The aim of the presented research was to analyze ceramic material based on cordierite as a function of activation time and sintering temperature. Threecomponent oxide mixture was prepared $(\mathrm{MgO}+\mathrm{Al} 2 \mathrm{O} 3+\mathrm{SiO} 2$ in the ratio 2:2:5). To decrease the sintering temperature, 10 mass $\% \mathrm{Bi} 2 \mathrm{O} 3$ was added to this mixture. The mixtures were mechanically activated for 5 and 240 minutes in a ceramic ball mill. Activated mixtures were sintered at temperatures of 1173-1573K. XRD method was used to determine the structural transformations of the obtained products.
\end{abstract}

Keywords: cordierite, activation, XRD

\section{INTRODUCTION}

Cordierite ceramics are formed during the sintering process in a narrow temperature "window" $(\Delta \mathrm{t}>283 \mathrm{~K})$ at temperatures above 1573K (Obradović et al. 2016; Obradović et al. 2019a). Cordierite has a low coefficient of expansion, good mechanical properties and a low dielectric constant. It is most widely used in places of sudden temperature changes. In order to lower the sintering temperature, bismuth oxide was added to the basic cordierite mixture, and mechanical activation was performed to determine its influence on the formation of this electronic ceramic.

The activation of materials is widely used as a procedure for bringing energy to the system so that it begins to react in a controlled manner. This allows the system to skip over the "energy barrier" on the reaction path (Baláž, 2003; Maciá-Agulló et al. 2004; Wang et al. 2005; Castro et al. 2004). The method of mechanical activation, which, in

\footnotetext{
${ }^{1}$ Institute for Technology of Nuclear and Other Row Materials, F. d'Esperey 86, Belgrade, Serbia ${ }^{2}$ Institute of Health Care Engineering with European Testing Center of Medical Devices TU Graz, Stremayrgasse 16, Graz, Austria
} 
various technical and technological ways, brings mechanical energy to solid materials thus changing and regulating many physico-chemical characteristics related to increasing the system's reactivity, is becoming more and more topical (Berbenni et al. 2001; Xue et al. 2002; Praveenkumer et al. 2008).

Additives can decrease the reaction temperature during sintering. Application of additives should improve the contact between reacting components during sintering process. Additive with lower melting point than reacting components temperature should enable the formation of the liquid phase in the system, and improve the contact between mixture components. It is also important that the additive ionic radius should be high enough not to upgrade itself into the crystal structure of cordierite (Kumar et al. 2014; Maurya et al. 2009; Obradović et al. 2019b).

\section{EXPERIMENTAL PROCEDURE}

In presented research the technical quality oxides $\mathrm{MgO}$ (purity 98.60\%, Euro Hemija, Beograd), Al2O3 (purity 99.19\%, Aluminijumski kombinat Podgorica), $\mathrm{SiO} 2$ (purity $96.10 \%$, Bela Reka) and $\mathrm{Bi} 2 \mathrm{O} 3$ (purity $99.98 \%$, Реахим) were used. $\mathrm{Bi} 2 \mathrm{O} 3$ have the melting point near $1093^{\circ} \mathrm{C}$. The mixture of $\mathrm{MgO}+\mathrm{Al} 2 \mathrm{O} 3+\mathrm{SiO} 2$ content in 2:2:5 ratio, with addition $10 \% \mathrm{Bi} 2 \mathrm{O} 3$, was mechanochemically activated. Activation periods were 5 and 240 minutes (mixtures designated B1 and B6) in cylindrical ceramic mill with balls (VEB, model $13 \times 10,5$ '). Table 1. presents the samples designations and corresponding milling times.

Activated samples were prepared as the tablets of radius of $8 \mathrm{~mm}$ and $4 \mathrm{~mm}$ high, obtained with pressure of $1 \mathrm{t} / \mathrm{cm}^{2}$. Samples activated for 5 minutes were sintered at the temperatures of $1273 \mathrm{~K}$ and $1373 \mathrm{~K}$ (sample B1). Samples of 240 minutes activation period were sintered at the temperatures of $1173 \mathrm{~K}, 1273 \mathrm{~K}, 1373 \mathrm{~K}, 1473 \mathrm{~K}$ and $1573 \mathrm{~K}$ (samples B6).

Sintered samples were analyzed using X-ray diffraction "Philips" XRD model PW-1710, with curved graphite monochromatic and scintillated counter. Intensities of diffracted $\mathrm{CuK}_{\alpha} \mathrm{X}$-ray radiation $(\lambda=11.54178 \AA$ ) were measured on the room temperature in 0.02 $2 \theta$ intervals and $0.25 \mathrm{~s}$ time intervals in range of $5^{\circ}$ to $85^{\circ} 2 \theta$. Rö tube was working at the $4 \mathrm{kV}$ voltage and at $3 \mathrm{~mA}$ current, with collimator angle of $1^{\circ}$ and with $0.1 \mathrm{~mm}$.

Table 1 Milling times and sample designations

\begin{tabular}{ll}
\hline Sample & Milling time \\
\hline B1 & $5 \mathrm{~min}$ \\
B6 & $240 \mathrm{~min}$ \\
\hline
\end{tabular}




\section{RESULTS AND DISCUSSION}

$\mathrm{XRD}$ analysis of the experimental cordierite mixture activated 5 minutes and sintered at $1273 \mathrm{~K}(\mathrm{~B} 1 / 1273 \mathrm{~K})$ did not detect the presence of cordierite. XRD analysis of the same sample sintered at the $1373 \mathrm{~K}$ (B1/1373K) detected the presence of the indialite (cordierite modification) traces. Larger amounts of indialite were detected in samples activated 240 minutes and sintered at $1373 \mathrm{~K}$ (B6/1373K). Both XRD diffractograms of the B1, B6 samples sintered at 1373K are presented on the Figure 1.
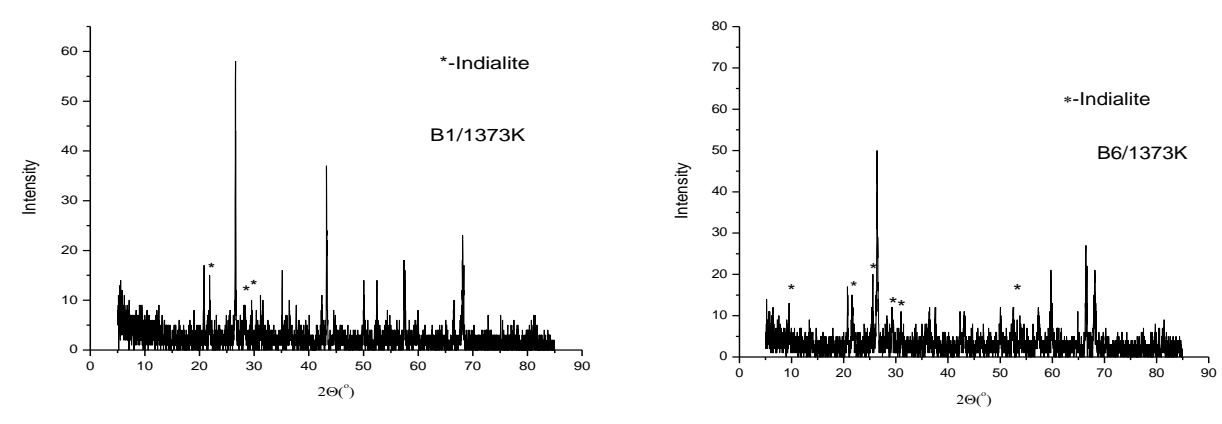

Figure 1 XRD analysis of samples B1(5 min) / 1373K and B6 (240 min) / 1373K

Cordierite is formed at the sintering temperatures above $1573 \mathrm{~K}$ with no additives, so the influence of the mechanochemical activation and additive due to the obtained results is clearly visible. The activation decreases the size of the mixture particles and increases the free active particle surface. This has direct influence on the kinetics of sintering.

The kinetics of cordierite forming in the experimental samples obtained at higher temperatures was analyzed. XRD diffractogram of sample sintered at temperatures $1473 \mathrm{~K}$ to $1573 \mathrm{~K}$, where even more amounts of indialites were detected, are presented at the Figure 2 and 3. 


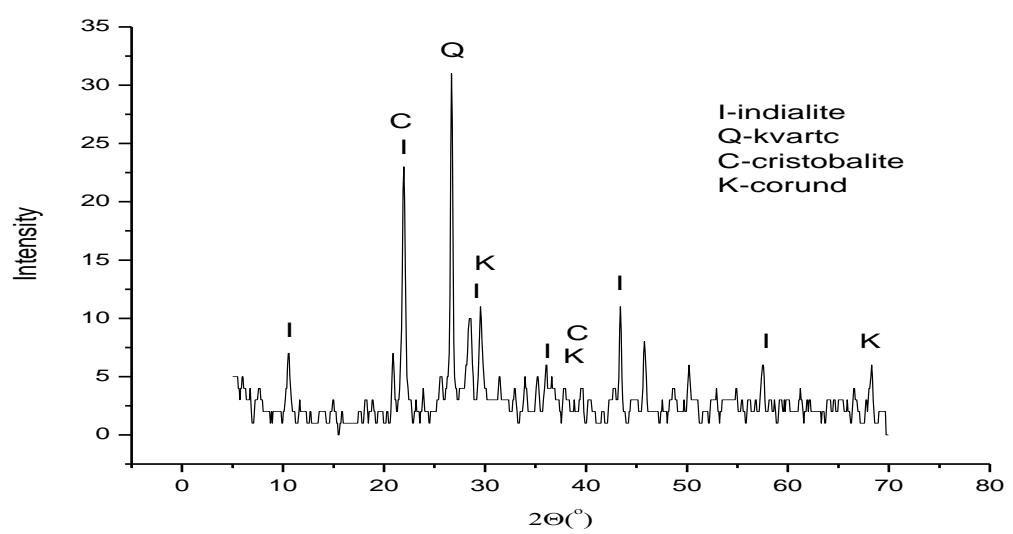

Figure 2 XRD diffractogram B6 (240 min) / 1473K

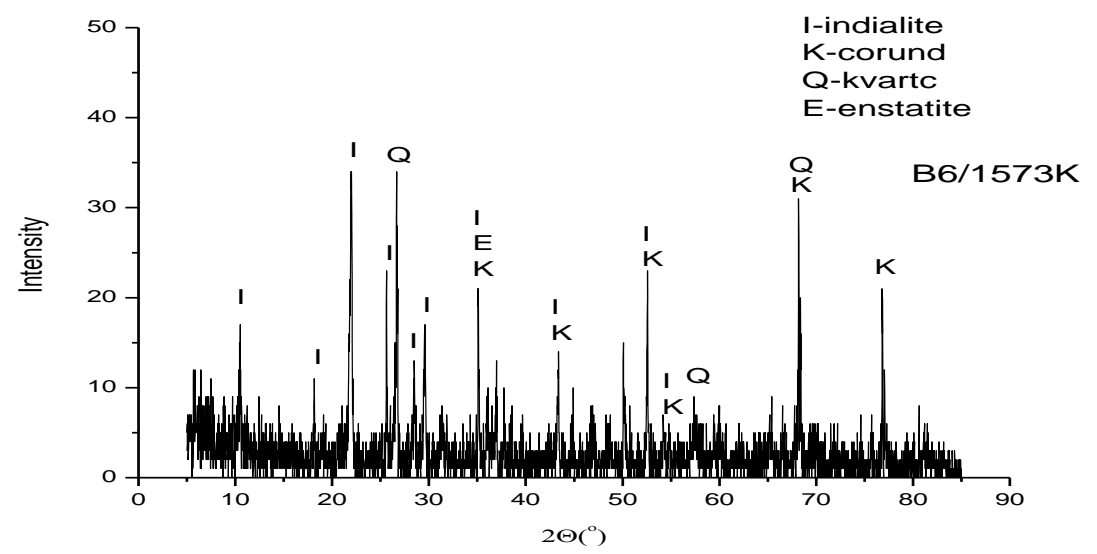

Figure 3 XRD diffractogram B6 (240 min) / 1573K

The performed experiments proved the stated assumption that mechanochemical activation has influence on cordierite forming temperature.

\section{CONCLUSION}

Presented research was done in purpose to investigate the effect of mechanical activation and sintering temperature on cordierite ceramics. Analysis presents the traces of intialite (cordierite modification) at the sintering temperature of 1373K. Higher amounts of intialite were detected at the same sintering temperature and activation period of 240 minutes at the same sintering temperature for the same activation time. Amount of produced inialite increase due to sintering temperature increase, and the highest gradient 
is between $1373 \mathrm{~K}$ and $1573 \mathrm{~K}$. The obtained results prove the existence of the activation time influence on the formation temperature of cordierite ceramics.

\section{ACKNOWLEDGMENTS}

This work was financially supported by the Ministry of Education, Science and Technological Development of the Republic of Serbia (Grant Nos. 451-03-9/202114/200023).

\section{REFERENCES}

OBRADOVIĆ, N. et al. (2016) Effects of Mechanical Activation and Two-Step Sintering on The Structure and Electrical Properties of Cordierite-Based Ceramics. Ceramics International, 42(12), pp. 13909-13918.

OBRADOVIĆ, N. et al. (2019a) Kinetics of Thermally Activated Processes in Cordierite-Based Ceramics. Journal Of Thermal Analysis and Calorimetry, 138(5), pp. 2989-2998.

BALÁŽ, P., (2003) Mechanical Activation In Hydrometallurgy in International Journal of Mineral Processing, 72(1-4), pp. 341-354.

MACIÁ-AGULLÓ, J. et al. (2004) Activation Of Coal Tar Pitch Carbon Fibres: Physical Activation Vs. Chemical Activation. Carbon, 42(7), pp. 1367-1370.

WANG, Y. et al. (2005) Visualizing the mechanical activation of Src. Nature, 434, pp. 1040-1045.

CASTRO, A. et al. (2004) Sodium Niobate Ceramics Prepared by Mechanical Activation Assisted Methods. Journal of the European Ceramic Society, 24(6), pp. 941-945.

BERBENNI, V., MARINI, A., BRUNI G. (2001) Effect Of Mechanical Activation On The Preparation Of SrTiO3 And Sr2TiO4 Ceramics From The Solid State System Srco3TiO2. Journal of Alloys and Compounds, 329(1-2), pp. 230-238.

XUE, J.M., WAN, D.M, WANG, J. (2002) Functional Ceramics Of Nanocrystallinity By Mechanical Activation. Solid State Ionics, 151(1-4), pp. 403-412.

PRAVEENKUMAR, B. et al. (2008) Investigation And Characterization Of La-doped PZT Nanocrystalline Ceramic Prepared By Mechanical Activation Route. Materials Chemistry and Physics, 112(1), pp. 31-34.

KUMAR, A. et al. (2014) Ultra High Strain Properties of Lanthanum Substituted PZT Electro-Ceramics Prepared Via Mechanical Activation. Journal of Alloys and Compounds, 599, pp. 53-59. 
MAURYA, D. et al. (2009) BiFeO3 Ceramics Synthesized By Mechanical Activation Assisted Versus Conventional Solid-State-Reaction Process: A Comparative Study. Journal of Alloys and Compounds, 477(1-2), pp. 780-784.

OBRADOVIĆ, N. et al. (2019b) The Effect Of Mechanical Activation On Synthesis And Properties Of MgAl2O4 Ceramics. Ceramics International, 45(9), pp.12015-12021. 